\title{
Endoscopic retrograde cholangio-pancreatography practice in district general hospitals in North East England: a Northern Regional Endoscopy Group (NREG) study
}

\author{
${ }^{1} \mathrm{~S}$ Chatterjee, ${ }^{2} \mathrm{C}$ Rees, ${ }^{3} \mathrm{AD}$ Dwarakanath, ${ }^{4} \mathrm{R}$ Barton, ${ }^{5} \mathrm{C}$ MacDonald, ${ }^{6} \mathrm{G}$ Greenaway, ${ }^{4} \mathrm{~W}$ Gregory, ${ }^{7} \mathrm{~A}$ \\ Reddy, ${ }^{8}$ DL Nylander \\ ${ }^{1}$ Specialist Registrar in Gastroenterology, Sunderland Royal Hospital, Sunderland, UK; ${ }^{2}$ Consultant Gastroenterologist South Tyneside \\ Hospital, South Shields, UK; ${ }^{3}$ Consultant Gastroenterologist University Hospital of North Tees, Stockton-on-Tees, UK; ${ }^{4}$ Consultant \\ Gastroenterologist Northumbria Healthcare NHS Trust, Tyne \& Wear, UK; ${ }^{5}$ Consultant Gastroenterologist Cumberland Infirmary, Carlisle, \\ UK; ${ }^{6}$ Consultant Gastroenterologist James Cook University Hospital, Middlesbrough, UK; ${ }^{7}$ Consultant Gastroenterologist Queen Elizabeth \\ Hospital, Gateshead, UK; ${ }^{8}$ Consultant Gastroenterologist Sunderland Royal Hospital, Sunderland, UK
}

\section{ABSTRACT}

Aim: Endoscopic retrograde cholangio-pancreatography (ERCP) is an important tool for the management of pancreato-biliary disease. The aim of this study was to compare the current practice of ERCP in North East England against the key 2004 National Confidential Enquiry Report into Patient Outcome and Death (NCEPOD) recommendations and the standards set by the Joint Advisory Group on Gastrointestinal Endoscopy (JAG).

Methods: This was a prospective multicentre study involving all hospitals in North East England, coordinated through the Northern Regional Endoscopy Group (NREG).

Results: Fourteen endoscopy units submitted data for 48I ERCPs. Mean dose of midazolam was $3.24 \mathrm{mg}$ (standard deviation I.35; range I-8 mg). Coagulation profile results were available on 469 patients (97\%). Radiological investigations were documented in $96 \%$ of the procedures (463 of $48 \mathrm{I}$ ) prior to ERCP.The most common indication for ERCP was related to choledocholithiasis and its complications. All procedures were performed with a therapeutic intent. A total of $84 \%$ of all patients were either American Society of Anesthesiologists grade I or II. The selective biliary cannulation rate was $87.3 \%$. The total completion rate of all procedures was $80.2 \%$ (38I of 475 ) and completion of therapy was $89.5 \%$ (425 of 475 ). The 30 -day mortality rate was $2 \%$ (ten patients) and procedure-related complications occurred in $5 \%$ of patients. There were no deaths directly as a result of ERCP; all deaths were related to underlying medical conditions.

Conclusions: The practice of ERCP in North East England adheres to the key recommendations of the NCEPOD and the standards set by JAG. The rates of complications compare favourably with those reported internationally.

KEYWORDS Endoscopic retrograde cholangio-pancreatography, North East England.
Correspondence to S Chatterjee, Department of Gastroenterology, Sunderland Royal Hospital, Kayll Road, Sunderland, Tyne and Wear SR4 7TP, UK

tel. +44 (0)7793 286576 e-mail suvadip_chatterjee@yahoo.com

DECLARATION OF INTERESTS No conflict of interests declared.

\section{INTRODUCTION}

Endoscopic retrograde cholangio-pancreatography (ERCP) is an important diagnostic and therapeutic modality for the management of pancreato-biliary disease. In 2007, the British Society of Gastroenterology (BSG) published results of a prospective audit examining ERCP practice in five metropolitan regions of England. 'This audit followed the 2004 report of the UK's National Confidential Enquiry into Patient Outcome and Death (NCEPOD) which had identified deficiencies in a number of areas. ${ }^{2}$ The aim of our audit was to compare the quality of ERCP practice in district general hospitals (DGHs) in the northeast of England against the key recommendations of the NCEPOD report ${ }^{2}$ (Table I) and the standards set by the Joint Advisory Group on Gastrointestinal Endoscopy (JAG) for certification in ERCP. The audit was coordinated through the Northern Regional Endoscopy Group (NREG).

\section{METHODS}

The hospitals in the north-east region serve a total population of 3.5 million. There is representation of all hospitals in NREG and through this organisation ERCP endoscopists were invited to participate and provide data on all ERCP procedures during the audit period (JuneAugust 2009). An ERCP procedure was defined as any endoscopic procedure that was performed with an intention to cannulate the common bile duct (CBD) or the pancreatic duct. A questionnaire was developed to capture the relevant demographic, clinical and procedurerelated data. Data were collected prospectively over a 
TABLE I Key recommendations of the National Confidential Enquiry into Patient Outcome and Death ${ }^{2}$ relevant to endoscopic retrograde cholangio-pancreatography (ERCP)

\begin{tabular}{|l|l|l|}
\hline Area of practice & NCEPOD findings & NCEPOD recommendations \\
\hline Consent & $\begin{array}{l}\text { No written consent in 2I\% of patients who died; } \\
16 \% \text { of deaths in patients with acute confusion } \\
\text { or dementia but written consent present in two- } \\
\text { thirds of these }\end{array}$ & $\begin{array}{l}\text { Risks/benefits to be explained to all patients } \\
\text { The ability of those with dementia or acute } \\
\text { confusion to provide consent to be tested }\end{array}$ \\
\hline Patient preparation & $\begin{array}{l}\text { In } 80 \% \text { of ERCPs there was no record of clotting } \\
\text { tests }\end{array}$ & $\begin{array}{l}\text { Bilirubin and clotting results to be available } \\
\text { before ERCP }\end{array}$ \\
\hline Sedation and monitoring & I4\% of cases inappropriately (excessively) sedated & Unit protocol for administration of sedation \\
\hline Training and education & $\begin{array}{l}\text { II\% of deaths were related to ERCPs performed } \\
\text { by an endoscopist performing <50 procedures } \\
\text { per year }\end{array}$ & $\begin{array}{l}\text { National guidelines for assuring continuing } \\
\text { competency recommended } \\
\text { All units to audit deaths within 30 days of ERCP }\end{array}$ \\
\hline $\begin{array}{l}\text { Patient selection, } \\
\text { assessment and outcome }\end{array}$ & $\begin{array}{l}77 \% \text { of deaths following ERCP were among those } \\
\text { with American Society of Anesthesiologists grade } \\
\text { III-V }\end{array}$ & $\begin{array}{l}\text { Patients to be reviewed by consultant } \\
\text { endoscopist before ERCP to ensure procedure } \\
\text { is appropriate and optimised }\end{array}$ \\
\hline
\end{tabular}

Adapted from Williams EJ, Taylor S, Fairclough P et al. Are we meeting the standards set for endoscopy? Results of a large-scale prospective survey of endoscopic retrograde cholangio-pancreatograph practice. Gut 2007; 56:82I-829.

three-month period at the time of the procedures. Nurseassessed sedation and comfort levels (see Appendix I; see online material at http://www.rcpe.ac.uk/journal/issue/4I2.php for Appendices) were recorded by the endoscopist immediately after the procedures.

The BSG have published a consensus document ${ }^{3}$ regarding consent, and details about the consent process were also collected.The endoscopists were asked to review patients immediately after the procedure and then review case notes 30 days or more after the procedure to capture immediate and delayed adverse events. In the case of an adverse event, the endoscopist reviewed the hospital records in detail to identify the type, severity and outcome of the event. The criteria for the diagnosis of post-ERCP complications are summarised in Table 2. Anonymised patient data were analysed using the SPSS statistical software (Version 17.0 SPSS Inc).

\section{RESULTS}

\section{Demographics of the patient population}

Fourteen endoscopy units submitted data for 48I ERCP procedures. Of these, 303 procedures $(63 \%)$ were carried out on females. The mean age of patients was 69 years with no difference between sexes. There were 139 patients with American Society of Anesthesiologists (ASA) grade I (mean age 60.8 years); 19I patients with grade II (mean age 7I.9I years); 57 patients with grade III (mean age 77.88 years); and six patients with grade IV (mean age 80.5 years). A total of 88 questionnaires did not contain a record of patient ASA scores (see Appendix II).

\section{Sedation}

All but three procedures (which were performed with general anaesthesia) were performed with conscious
TABLE 2 Definitions of post-endoscopic retrograde cholangio-pancreatography complications

\begin{tabular}{|c|c|c|c|}
\hline & Mild & Moderate & Severe \\
\hline $\begin{array}{l}\text { Pancreatitis } \\
\text { (abdominal } \\
\text { pain and } \\
\text { amylase } \\
>3 x \text { above } \\
\text { normal after } \\
24 \text { hours) }\end{array}$ & $\begin{array}{l}\text { Requiring } \\
\text { admission or } \\
\text { prolongation } \\
\text { of planned } \\
\text { admission to } \\
>2 \text { nights }\end{array}$ & $\begin{array}{l}\text { Requiring } \\
4-10 \text { days in } \\
\text { hospital }\end{array}$ & $\begin{array}{l}\text { Admission } \\
\text { for > I0 days; } \\
\text { haemorrhagic } \\
\text { pancreatitis; } \\
\text { pseudocyst; } \\
\text { intervention } \\
\text { required; } \\
\text { death }\end{array}$ \\
\hline $\begin{array}{l}\text { Infection } \\
\text { (Cholangitis) }\end{array}$ & $\begin{array}{l}>38^{\circ} \mathrm{C} \text { for } \\
\mathrm{I}-2 \text { days }\end{array}$ & $\begin{array}{l}\text { Febrile or } \\
\text { septic illness } \\
\text { requiring } \\
>3 \text { days in } \\
\text { hospital or } \\
\text { endoscopic/ } \\
\text { percutaneous } \\
\text { intervention }\end{array}$ & \begin{tabular}{|l|} 
Septic shock \\
or surgery; or \\
resulting in \\
death
\end{tabular} \\
\hline Bleeding & $\begin{array}{l}\text { Clinical } \\
\text { (not just } \\
\text { endoscopic), } \\
\text { drop in Hb } \\
\text { >3 gm\%; no } \\
\text { transfusion }\end{array}$ & $\begin{array}{l}\text { Transfusion } \\
\text { (4 units or } \\
\text { less); no } \\
\text { angiographic } \\
\text { or surgical } \\
\text { intervention }\end{array}$ & $\begin{array}{l}\text { Transfusion } \\
>5 \text { units; } \\
\text { angiographic } \\
\text { or surgical } \\
\text { intervention; } \\
\text { death }\end{array}$ \\
\hline Perforation & 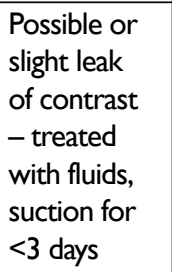 & $\begin{array}{l}\text { Any definite } \\
\text { perforation } \\
\text { treated } \\
\text { conservatively } \\
\text { for } 4-10 \text { days }\end{array}$ & $\begin{array}{l}\text { Hospitalisation } \\
\text { for }>10 \text { days; } \\
\text { need for } \\
\text { intervention } \\
\text { (percutaneous } \\
\text { or surgical); } \\
\text { death }\end{array}$ \\
\hline
\end{tabular}

Adapted from Cotton PB, Lehman G, Vennes J et al. Endoscopic sphincterotomy complications and their management: an attempt at consensus. Gastrointest Endosc 1991; 37:388-93. 
TABLE 3 Sedation at endoscopic retrograde cholangiopancreatography

\begin{tabular}{|l|l|l|l|l|}
\hline & $\begin{array}{l}\text { No. of pro- } \\
\text { cedures }\end{array}$ & $\begin{array}{l}\text { Dosage } \\
\text { range } \\
\text { (mg) }\end{array}$ & $\begin{array}{l}\text { Mean } \\
\text { dosage } \\
\text { (mg) }\end{array}$ & $\begin{array}{l}\text { Standard } \\
\text { deviation }\end{array}$ \\
\hline Midazolam & 439 & $1-8$ & 3.24 & 1.35 \\
\hline Fentanyl & 145 & $10-100$ & 48.43 & 21.12 \\
\hline Pethidine & 310 & $12-75$ & 36.45 & 13.29 \\
\hline Diazepam & 29 & $5-30$ & 12.33 & 6.37 \\
\hline
\end{tabular}

sedation. Sedation was with benzodiazepine +/- opioid. Midazolam was the benzodiazepine used in $92 \%$ of sedated cases; mean dose administered was $3.24 \mathrm{mg}$ (standard deviation I.35; range $1-8 \mathrm{mg}$ ). The opioids pethidine and fentanyl were used (usually in conjunction with benzodiazepine) in $310(65 \%)$ and $145(30 \%)$ procedures respectively. Table 3 summarises the drugs used in all procedures. Buscopan was used in 385 (81\%) procedures; mean dosage $27 \mathrm{mg}$ (range $10-100 \mathrm{mg}$ ). No patient required reversal of benzodiazepine or opiate. In our patient population, 17\% (82 patients) received additional throat spray along with sedation. This group did not suffer any additional complications related to the concurrent usage of sedation and throat spray.

\section{Consent}

Information regarding consent was available in 474 out of $48 \mathrm{I}$ procedures. Seven questionnaires did not document any information about the process of consent. Signed consent forms were available prior to the patient reaching the endoscopy suite/x-ray department in 415 patients (86.3\%), and 59 patients $(12.3 \%)$ had their consent process completed by the clinician performing the ERCP just prior to the procedure.

\section{Investigations and pre-ERCP imaging}

Coagulation profile results were available on 469 patients (97\%), all less than seven days prior to the procedure. In the remaining questionnaires, there was no record of this having been checked. Platelet count was available in 466 patients (97\%) and 15 questionnaires had missing data. Mean prothrombin time (PT) was 13.1 seconds (range 12-30) and mean platelet count was 308 (range 58-962).

Ultrasound of the abdomen was the most frequent radiology imaging modality performed prior to ERCP. In 390 out of 481 (82\%) procedures, there was record of an ultrasound report in the notes prior to the procedure. Eighteen questionnaires had no record of radiology imaging and all these procedures involved stent removal, previous failed ERCP or stenting for bile duct injury. Table 4 summarises other radiological procedures performed in addition to transabdominal ultrasound prior to ERCP.

\section{Indications, therapy and completion of procedure}

The most common indication for ERCP in this study was choledocholithiasis (56\%). The other indications were
TABLE 4 Radiological investigations prior to endoscopic retrograde cholangio-pancreatography (ERCP)

\begin{tabular}{|l|l|l|l|}
\hline & $\begin{array}{l}\text { Ultrasound } \\
\text { prior to ERCP }\end{array}$ & $\begin{array}{l}\text { No ultra- } \\
\text { sound prior } \\
\text { to ERCP }\end{array}$ & Total \\
\hline CT abdomen & 123 & 30 & 153 \\
\hline $\begin{array}{l}\text { Magnetic resonance } \\
\text { cholangio- } \\
\text { pancreatography }\end{array}$ & $\mathrm{I} 46$ & 32 & 178 \\
\hline $\begin{array}{l}\text { Endoscopic } \\
\text { ultrasound }\end{array}$ & 6 & $\mathrm{I}$ & 7 \\
\hline Previous ERCP & $\mathrm{I}$ & 10 & $\mathrm{II}$ \\
\hline No other imaging & $\mathrm{I} 14$ & 18 & \\
\hline Total & 390 & $9 \mathrm{I}$ & $48 \mathrm{I}$ \\
\hline
\end{tabular}

abnormal liver function tests (44\%), cholangitis (21\%), abdominal pain (19\%), biliary dilatation on imaging (15\%), pancreatic mass (8\%), surgical bile duct injury (1.2\%), recent acute pancreatitis due to stones (4\%), stent removal $(6.6 \%)$ and others (3\%). In this audit, selective deep cannulation of the bile duct was achieved in 420 cases (87.3\%). Therapeutic procedures were as follows: 300 sphincterotomies (71\%), I 63 biliary stent placements (38\%), 65 balloon trawls (15\%), 50 basket trawls (I2\%), I4 stent removals (3.4\%), ten mechanical lithotripsies (2\%), four needle knife accesses, two balloon sphincteroplasties and one pancreatic duct stenting were performed. Data regarding completion and difficulty grade of ERCP (Appendix III) were available in 475 procedures. Tables 5 and 6 summarise the success of the procedures against the difficulty grades of ERCP and ASA grade of patients.

TABLE 5 Endoscopic retrograde cholangio-pancreatography (ERCP) completion and difficulty grading of ERCP

\begin{tabular}{|l|l|l|l|l|}
\hline $\begin{array}{l}\text { Difficulty grade of } \\
\text { ERCP }\end{array}$ & $\begin{array}{l}\text { I } \\
\mathbf{( 9 2 \% )}\end{array}$ & $\begin{array}{l}\text { II } \\
\mathbf{( 7 . 3 \% )}\end{array}$ & $\begin{array}{l}\text { III } \\
\mathbf{( 0 . 7 \% )}\end{array}$ & Total \\
\hline Procedure complete & $35 \mathrm{I}$ & 28 & 2 & $38 \mathrm{I}$ \\
\hline $\begin{array}{l}\text { Incomplete but } \\
\text { successful therapy or } \\
\text { palliation }\end{array}$ & 33 & $\mathrm{II}$ & 0 & 44 \\
\hline Unsuccessful & 43 & 6 & $\mathrm{I}$ & 50 \\
\hline Total & 427 & 45 & 3 & 475 \\
\hline
\end{tabular}

TABLE 6 Endoscopic retrograde cholangiopancreatography (ERCP) completion and American Society of Anesthesiologists (ASA) grading

\begin{tabular}{|l|l|l|l|l|}
\hline & ASA I & ASA II & ASA III & ASA IV \\
\hline $\begin{array}{l}\text { Procedure } \\
\text { complete }\end{array}$ & 116 & 150 & 47 & 5 \\
\hline $\begin{array}{l}\text { Incomplete } \\
\text { but successful } \\
\text { palliation }\end{array}$ & 8 & 19 & 4 & 0 \\
\hline Unsuccessful & 15 & 22 & 6 & I \\
\hline Total & 139 & 191 & 57 & 6 \\
\hline
\end{tabular}


TABLE 7 Sedation and comfort scores

\begin{tabular}{|l|l|l|}
\hline Score & Sedation score (\%) & Comfort score (\%) \\
\hline $\mathbf{0}$ & $49(10 \%)$ & $29(6 \%)$ \\
\hline I & $60(12 \%)$ & $174(36.2 \%)$ \\
\hline II & $272(56.5 \%)$ & $183(38.2 \%)$ \\
\hline III & $75(15.6 \%)$ & $70(14.6 \%)$ \\
\hline IV & $8(1.7 \%)$ & $13(2.7 \%)$ \\
\hline V & $5(1 \%)$ & N/A \\
\hline
\end{tabular}

Procedure time, screening time and sedation/ discomfort scores

Procedure time was defined as the time from scope insertion to scope extubation and this was recorded in 383 questionnaires. Mean procedure time was 24 minutes (range 2-100 minutes). The screening time was defined as the total duration of time the fluoroscopy machine was active during the procedure. This was recorded in 356 procedures. Procedure screening time ranged from 6-890 seconds with a mean of 193 seconds.

Table 7 gives sedation and comfort score details of all procedures. Data relating to sedation and comfort scores were missing in 12 questionnaires.

\section{Complications}

There were ten reported deaths ( $2 \%$ of all procedures performed) within 30 days of ERCP procedure (see Table 8). Other complications noted were cholangitis (four; $0.8 \%$ ), pancreatitis (five; $1 \%$ ), bleeding (five; $1 \%$ ), perforation (one; $0.2 \%$ ), abdominal pain requiring hospital admission in nine patients ( $1.8 \%$ ), hepatic abscess in one patient $(0.2 \%)$, thought to be as a result of ascending cholangitis post-procedure.

\section{DISCUSSION}

This is the first audit of the current practice of ERCP in DGHs in North East England. It was arranged via NREG. Fourteen hospitals participated in the study which represents $95 \%$ of all endoscopists providing ERCP service in this region.

For the purposes of this study, ERCP was deemed 'complete' only if the intended intervention was fully performed. In certain situations, when this could not be completed but the endoscopist was able to do an intermediate intervention as a bridge to the final procedure at a later date (e.g. insertion of CBD stent when the duct could not be cleared of stones) it was termed 'incomplete but with successful therapy or palliation'. Deep cannulation of the bile duct was said to have been achieved when the distal CBD was entered sufficiently to be able to attempt the intended treatment.The minimum acceptable deep cannulation rate for a trained endoscopist for grade I ERCPs is between $80-90 \%{ }^{3.4}$ The UK Joint Advisory group on Gastrointestinal Endoscopy has indicated that to be accredited as an independent ERCP endoscopist, an individual must show satisfactory completion of the intended therapeutic procedure in grade I ERCPs in more than $80 \%$ of cases. ${ }^{3}$ In our study, the selective deep bile duct cannulation rate was $87.3 \%$ ( 420 out of 481 ). The total completion rate (see Table 5) for all procedures was $80.2 \%$ (38I out of 475) and completion of therapy was $89.5 \%$ (425 out of 475); both of which meet the standards set by JAG.

Most of the patients were either ASA grade I or II (a total of 330 out of 393 patients, $84 \%$ ). Only 63 patients (16\%) were ASA grade III or IV. This reflects appropriate patient selection and is in sharp contrast to the NCEPOD report ${ }^{2}$ that had inferred that potentially large numbers of inappropriate procedures are being carried out on 'high-risk' patients. There was no documentation of ASA grading in 88 questionnaires as three endoscopy units in the region did not routinely assess ASA grading.

There was a general supposition by the NCEPOD ${ }^{2}$ which was also noted by Williams et al.' that ERCP is performed without appropriate checks such as clotting and radiological investigations. In this study, the converse was the case. Only 18 patients did not have documented imaging prior to ERCP and all of them were patients who had a previous ERCP and had come for either a stent removal or second attempt at therapy and repeat radiological investigations were not indicated. All patients had coagulation parameters checked prior to the procedure.

Now predominantly a therapeutic procedure, the diagnostic role of ERCP has been superseded by other radiological modalities. In this current study, all patients underwent ERCP with a therapeutic intent and 318 (72\%) had some therapeutic intervention done. This is in keeping with the current belief that ERCP should not be routinely used for diagnostic purposes. In our study, the most common indication for ERCP was choledocholithiasis with most of the procedures being difficulty grade I ( 427 of $475 ; 90 \%$ ).

The complication rates of ERCP have been studied in great detail previously both in the UK and in the United States.' Our study reported an overall complication rate of $5 \%$ which is similar to previous reports. ${ }^{5-10}$ The 30 -day mortality rate was $2 \%$ ( 10 patients) amongst all procedures performed. Four patients died of progressive malignancy within 30 days of the procedure. The other six deaths were all related to complications of the patients' medical condition, and there were no deaths as a direct result of the ERCP procedure itself such as bleeding, perforation, newly induced sepsis, or pancreatitis. This mortality rate and risk of complications are comparable to previously published data from the UK and North America. ${ }^{5-9}$ Our study did not demonstrate a correlation between rate of complication with either the difficulty of the procedure or with ASA grade of the patient $(p=0.8)$. This observation is due to correct patient selection (only a few patients were of ASA grade III and IV) and more difficult ERCPs (grade 
III) are usually done in the regional referral unit and therefore not included in this study.

As there are no universally accepted comfort and sedation scoring systems, we used systems which were agreed by all the authors prior to the commencement of the audit (see Appendix I). The BSG has recommended" that the mean dosage of midazolam for ERCP should be less than $5 \mathrm{mg}$ (3.24 mg in our study) and adverse events, such as usage of flumazenil for reversal of sedation should be recorded (not used in any of our patients in this study). This, we feel should be interpreted in conjunction with the sedation and discomfort scores and procedure times. Mean procedure time was 24 minutes with only $2.7 \%$ patients getting a sedation and comfort score of more than III.

This study faced some limitations. Firstly, some of the audit questionnaires were incomplete. Secondly, the study failed to investigate the influence of trainees on ERCP lists. In North East England since the publication of the BSG audit' there has been a definite move towards training only a few nominated registrars (as per its recommendations) and there was no trainee performing or being trained in ERCP during the study period. Thirdly, it was not possible to compare the performance of participating centres due to a possibility of different case mix and small numbers of procedures in this study. Also, the number of procedures performed by each endoscopist was too small to make an individual assessment of their performance.

TABLE 8 Causes of mortality

\begin{tabular}{|c|c|c|}
\hline $\begin{array}{l}\text { Age } \\
\text { (yrs) }\end{array}$ & $\begin{array}{l}\text { Indication for endoscopic } \\
\text { retrograde cholangio- } \\
\text { pancreatography (ERCP) }\end{array}$ & Cause of death \\
\hline 70 & $\begin{array}{l}\text { Choledocholithiasis, proven } \\
\text { cholangitis prior to ERCP }\end{array}$ & Sepsis \\
\hline 69 & $\begin{array}{l}\text { Malignant biliary stricture } \\
\text { with cholangitis due to } \\
\text { biliary obstruction }\end{array}$ & Sepsis \\
\hline 84 & Choledocholithiasis & $\begin{array}{l}\text { Sepsis (pneumonia } \\
\text { three weeks later) }\end{array}$ \\
\hline 85 & $\begin{array}{l}\text { Choledocholithiasis with } \\
\text { cholangitis }\end{array}$ & Sepsis \\
\hline 85 & $\begin{array}{l}\text { Choledocholithiasis with } \\
\text { cholangitis }\end{array}$ & Sepsis \\
\hline 65 & Malignant biliary stricture & $\begin{array}{l}\text { Progressive } \\
\text { pancreatic malignancy }\end{array}$ \\
\hline 78 & Ampullary tumour & $\begin{array}{l}\text { Progressive } \\
\text { pancreatic malignancy }\end{array}$ \\
\hline 80 & Malignant biliary stricture & $\begin{array}{l}\text { Progressive } \\
\text { pancreatic malignancy }\end{array}$ \\
\hline 87 & Pancreatic cancer & \begin{tabular}{|l|} 
Progressive \\
pancreatic malignancy
\end{tabular} \\
\hline 83 & $\begin{array}{l}\text { Choledocholithiasis with } \\
\text { cholangitis }\end{array}$ & Frailty of old age \\
\hline
\end{tabular}

It is well known that publication of national audits gives us much needed insight into our daily practice. Deliberate introduction of practice changes in the post-audit era help us improve, and follow-up audits like this current one reassure ourselves of continued compliance with national standards. We believe that this audit has effectively reported current practice of ERCP in DGHs in North East England. It is clear that their endoscopy units have incorporated the findings (which have been audited in this study) of the NCEPOD enquiry report ${ }^{2}$ into their daily practice, to enable them to deliver the safest patient care.

\section{ACKNOWLEDGEMENTS}

The authors would like to thank all the participating units and members of staff who assisted in data collection and local coordination of the project.

\section{REFERENCES}

I Williams EJ, Taylor S, Fairclough P et al.Are we meeting the standards set for endoscopy? Results of a large-scale prospective survey of endoscopic retrograde cholangio-pancreatograph practice. Gut 2007; 56: 82 I-9. doi: I0. I 136/gut.2006.097543

2 National Confidential Enquiry into Patient Outcome and Death (NCEPOD). Scoping our practice; the 2004 Report of the National Confidential Enquiry into Patient Outcome and Death. London: NCEPOD; 2004. Available from http://www.ncepod.org.uk/2004.htm

3 Joint Advisory Group on Gastrointestinal Endoscopy (JAG) Guidelines on the training, appraisal and assessment of trainees in gastrointestinal endoscopy, London;JAG; 2004.Available from http:// www.bsg.org.uk/pdf_word_docs/jag_recommendations_2004.pdf

4 American Society for Gastrointestinal Endoscopy (ASGE). Principles of training in gastrointestinal endoscopy. Gastrointest Endosc 1999; 49:845-53. doi:I0.1016/S00 I6-5107(99)70316-0

5 Freeman ML. Adverse outcomes of ERCP. Gastrointest Endosc 2002;56(Suppl): S273-82. doi: I 0. I0 I6/S00 I6-5 I 07(02)70025-4

6 Freeman ML, Nelson DB, Sherman S et al.Complications of endoscopic biliary sphincterotomy. N Engl J Med 1996;335:909-18. doi:I0.1056/NEJMI9960926335I30I

7 Loperfido S, Angelini G, Beneditti G et al. Major early complications from diagnostic and therapeutic ERCP: a prospective multicenter study. Gastointest Endosc 1998; 48: I-I0. doi:I0.1016/S00 I6-5107(98)70I2I-X

8 Freeman ML, DiSario JA, Nelson DB et al. Risk factors for post -ERCP pancreatitis: a prospective, multicenter study. Gastrointest Endosc 200 I; 54:425-34. doi: 10.1067/mge.2001.I17550

9 Masci E, Toti G, Mariani A et al. Complications of diagnostic and therapeutic ERCP: a prospective multicenter study. Am J Gastroenterol 200I;96:4I7-23. doi:I0.I I I I/j.I572-024I.200I.03594.x

10 Christensen M, Matzen P, Schulze $S$ et al. Complications of ERCP: a prospective study. Gastrointest Endosc 2004; 60:72I-73I. doi:I0.1016/S0016-5107(04)02169-8

II British Society of Gastroenterology. Safety and sedation during endoscopic procedures. London: BSG, 2003. Available from http:// www.bsg.org.uk/clinical-guidelines/endoscopy/guidelines-onsafety-and-sedation-during-endoscopic-procedures.html 


\section{APPENDICES}

APPENDIX I Clinical guide to the Sedation and Discomfort Score

\begin{tabular}{|l|c|l|c|}
\hline Comfort definition & $\begin{array}{l}\text { Comfort } \\
\text { score }\end{array}$ & Sedation definition & $\begin{array}{l}\text { Sedation } \\
\text { score }\end{array}$ \\
\hline No/minimal discomfort & I & Fully awake; clear eyes; no ptosis & I \\
\hline $\begin{array}{l}\text { Mild discomfort - easily follows verbal } \\
\text { instructions }\end{array}$ & 2 & $\begin{array}{l}\text { Slightly drowsy; mild slowing/'thickening' of speech, } \\
\text { ptosis }\end{array}$ & 2 \\
\hline $\begin{array}{l}\text { Moderate discomfort - mild movements, can } \\
\text { be calmed by verbal instructions }\end{array}$ & 3 & $\begin{array}{l}\text { Asleep - easily rousable by directed voice. Slurred, } \\
\text { slowed speech }\end{array}$ & 3 \\
\hline $\begin{array}{l}\text { Severe discomfort-violent/ struggling, not } \\
\text { obeying instruction leading to abandonment. }\end{array}$ & 4 & $\begin{array}{l}\text { Deeply asleep - responds only to prodding/ shaking/ } \\
\text { shouting their name }\end{array}$ & 4 \\
\hline & & Unconscious - no response to noxious stimuli & 5 \\
\hline
\end{tabular}

APPENDIX II American Society of Anesthesiologists (ASA) scoring system

\begin{tabular}{|c|l|}
\hline ASA grade & Description of grade \\
\hline I & Normal healthy patient \\
\hline II & Mild systemic disease \\
\hline III & Severe systemic disease \\
\hline IV & $\begin{array}{l}\text { Severe systemic disease which is a } \\
\text { constant threat to life }\end{array}$ \\
\hline VI & $\begin{array}{l}\text { Moribund patient who is not expected to } \\
\text { survive with or without operation }\end{array}$ \\
\hline $\begin{array}{l}\text { A declared brain dead patient whose } \\
\text { organs are being removed for transplant } \\
\text { purposes. }\end{array}$ \\
\hline
\end{tabular}

"Adapted from the American Society of Anesthesiologists grading system. Saklad M. Grading of patients for surgical procedures. Anesthesiology 194I;2:28I-4.
APPENDIX III Grading of difficulty of endoscopic retrograde cholangio-pancreatography (ERCP)*

\begin{tabular}{|c|l|}
\hline Grade & Type of ERCP \\
\hline I & $\begin{array}{l}\text { Diagnostic cholangiogram, Brush } \\
\text { cytology, standard sphincterotomy, stone } \\
\text { removal }(\leq 10 \mathrm{~mm}), \text { stricture dilatation, } \\
\text { common duct stenting, naso-biliary drain, } \\
\text { sphincteroplasty, diagnostic pancreatogram }\end{array}$ \\
\hline II & $\begin{array}{l}\text { Billroth diagnostics, hilar stenting, removal of } \\
\text { stones (>10 mm) }\end{array}$ \\
\hline III & $\begin{array}{l}\text { Sphincter of Oddi manometry, Billroth } \\
\text { therapeutics, intrahepatic stone removal, all } \\
\text { pancreatic therapy }\end{array}$ \\
\hline
\end{tabular}

"This grading system is modified from the one proposed by Schutz SM, Abbott RM. Grading of ERCPs by degree of difficulty: a new concept to produce more meaningful outcome data. Gastrointest Endosc 2000; 51:535-539. 